\title{
Studying Languages in the Linguistic Landscape of Lijiang Old Town
}

\author{
$\mathrm{Na} \mathrm{Xia}{ }^{1} \&$ Lisheng $\mathrm{Li}^{1}$ \\ ${ }^{1}$ Foreign languages and literature, Yunnan Normal University, China \\ Correspondence: $\mathrm{Na} \mathrm{Xia}$, School of Foreign languages and literature, Yunnan Normal University, Kunming, \\ China. E-mail: xiana2005@126.com
}

Received: December 29, 2016

Accepted: January 26, 2016 Online Published: March 28, 2016

doi:10.5539/ijel.v6n2p105

URL: http://dx.doi.org/10.5539/ijel.v6n2p105

\begin{abstract}
As one of the new developments in the field of applied linguistics, linguistic landscape research has attracted many international scholars' attention in recent years. The research examined the types of language use and their distributions, especially the use of the bilingual and multilingual signs, and the attitudes of local governmental officials, shop owners or employees, domestic and international tourists towards the use of Chinese, Dongba scripts, and English. Both quantitative and qualitative methods were employed to explore the research subjects. To be specific, digital camera was used for data collection of quantitative analysis, and questionnaires and interviews were also adopted for qualitative analysis. The analyses of research results showed that the linguistic landscapes of Fuhui Street and Xinhua Street indicated significant difference.
\end{abstract}

Keywords: linguistic landscape, language use, Fuhui street, Xinhua street

\section{Introduction}

People all live in places surrounded by written signs, which are displayed on street names, posters, advertisements, official notices and messages, etc. As one of the relatively new developments in the field of applied linguistics and sociolinguistics, linguistic landscape research has attracted many international scholars' growing attention in recent years. More and more international scholars have devoted to the study of linguistic landscapes in different parts of the world. Landry \& Bourhis (1997) considered the linguistic landscape as certain context of sociolinguistic processes. Backhaus (2007) explored the empirical study of multilingual signs in Tokyo. Cenoz \& Gorter (2006) studied the linguistic landscape of two streets in two multilingual cities and analyzed the use of languages relating to language policy, to cite just a few examples. Obviously, studies of linguistic landscape mainly deal with languages in written forms in public places or spaces. On the whole, the research of LL has become one of the hot topics.

However, in China, there have been scanty scholars' studies focusing on the linguistic landscape. The relevant research related to signs in China has been mainly concentrating on English translations on public signs. Especially, the quality Chinese-English translation of signs has been the main focus. Therefore, the relevant mistake-finding and mistake-correcting processes have been conducted. Quite a few Chinese scholars have failed to pay adequate attention to the descriptive approach to studying the signs displayed in cities. Chinese Scholars began to use the term of "linguistic landscape" in 2009. After several years, mainly between 2014 and 2015, studies on linguistic landscape thrive, though there are not so many research outcomes. It is, therefore, of great significance to study the linguistic landscape in China, in particular in the multilingual contexts like Yunnan province.

\section{Literature Review on Linguistic landscape research}

\subsection{Linguistic Landscape Research Abroad}

Gorter (2006) pointed out that "the study of the linguistic landscape is a relatively new development" (p. 2). The research of linguistic landscape appeared recently in the field of sociolinguistics and began to enjoy a growing interest in sociolinguistics and applied linguistics. It is only since the end of 1990s that linguistic landscape has been received growing attention as a topic for research within sociolinguistics. Research on the field of linguistic landscapes is still new, and there is not a generally accepted approach or definition into linguistic landscapes. Though there have several methodological advances, there are still several scholars (Cenoz \& Gorter, 2008; Shohamy \& Gorter, 2009) have asserted no coherent and independent theory in the field now. The main concentration of linguistic landscape research is on the visibility and salience of written languages in the public 
research. Two pioneers, Landry \& Bourhis (1997), who did research on the linguistic landscape, defined the term in a specific way in their paper Linguistic landscape and ethno-linguistic vitality:

"The language of public road signs, advertising billboards, street names, place names, commercial shop signs, and public signs on government buildings combines to form the linguistic landscape of a given territory, region, or urban agglomeration.” (Landry \& Bourhis, 1997, p. 25)

Landry \& Bourhis investigated the role of linguistic landscape in ethnolinguistic vitality and language maintenance and their relations in Canada. The whole aim is to "consider the issue of linguistic landscape as an important sociolinguistic factor contributing to the vitality of competing ethnolinguistic groups in multilingual settings" (Landry \& Bourhis 1997, p. 24).

The above two pioneering works shed light on the informational marker and a marker of collective identity of linguistics landscape. It's essential because they paved the way for the illumination of the field of sociolinguistics. However, they still invited further aspects of discussions and considerations that were ignored or neglected. The Landry \& Bourhis approach did not pay much attention to the sociopolitical factors in the formation of linguistic landscape. Among many research outcomes, some scholars have published monographs, symposia, etc.. Backhaus (2007) published the monograph Linguistic Landscapes: a comparative study of urban multilingualism in Tokyo. Shohamy \& Gorter (2009) edited Linguistic Landscape: Expanding the scenery; Shohamy, Ben-Rafael, \& Barni (2010) edited the collected papers Linguistic landscape in the city. In addition to the above research results, there are also some specialized journals used to publish the themes on linguistic landscape. International Journal of Multilingualism (2006) is devoted to case studies of linguistic landscapes around the world. World Englishes (2012) publishes a series of specific topics on linguistic landscapes and mainly discusses the roles that English plays in the linguistic landscape. Specifically, Linguistic Landscapes: An International Journal was introduced in 2015 to publish research outcomes of the linguistic landscapes. This shows that the international linguistic landscape research is becoming more and more thriving.

\subsection{Linguistic Landscape Research in China}

International scholars have studied the linguistic landscape and achieved plenty of research results. Meantime, Chinesescholars began to pay attention to the linguistic landscape, and achieved some results. As a matter of fact, the domestic scholars have already started to study the public signs in 2002, which are quite different from the studies of linguistic landscape. Research on public signs is mostly from the perspective of translation. Consequently, the common research process is to find problems or mistakes in a certain area, and put forward corresponding improvement method, error correction and strategies. It is generally considered that the first study on translation of public signs is Bei Zhu \& Shan Aimin's On Linguistic Features Of English Public Signs and Chinese-English Translation in 2002. The article regarded the host of Olympic Games as the background. It discussed the public signs in Beijing based on a large number of Chinese English bilingual signs, and put forward the practical application function of the public signs, i.e. directing, prompting, restricting and mandatory. Finally, the author regulated the translation on Chinese-English translation of public signs. In 2005, the first national public signs translation seminar was held in Beijing International Studies University. Under this circumstance, there emerged a large number of scholars who conducted research on the translation of public signs. Ding Hengqi (2006) made efforts to improve the translation quality of urban public signs and gradually formed the reference translation. Zhao Xiang (2006) reviewed the research on the translation of public signs, and provided some new ideas for future research. Yang Yonghe (2009) based on the investigation and analysis of the research on the translation of public signs in the new century, mainly summarized the great achievements that Chinese scholars have made on public signs translation. Li Peidong (2015) analyzed the corpora of public sign translation and put forward the principle of macro translation from the perspective of critical linguistics. There are many other Chinese scholars who have been devoted to the research on public signs translation in China. It can be seen that the scope of the public signs translation studies is expanding and showing the interdisciplinary trend.

Research on public signs attaches great importance to the prescriptive property, which is along with some translation strategies or practical suggestions on translation. However, research on linguistic landscape is completely different. It emphasizes the descriptive property that describes the actual language use in a certain area, namely language fact. Under the influence of studies on linguistic landscape among international scholars, quite a few Chinese scholars begin to notice the study of linguistic landscape. Though Sun Li (2009) used the term "linguistic landscape", his research still focused on the translation, especially the status quo of linguistic landscape translation and the relevant communication strategies. From 2014 to 2015, the results of research on the linguistic landscape in China were productive. Shang Guowen \& Zhao Shouhui (2014a) firstly analyzed the 
perspective, theory and method of linguistic landscape research and defined the concept, function and main research content of the linguistic landscape. Then they discussed the methodology and theoretical framework of linguistic landscape. Finally, they put forward the challenges that linguistic landscape researchfaces. In the same year, Shang Guowen \& Zhao Shouhui (2014b) further indicated the epistemology, analysis of dimension and theoretical construction of linguistic landscape research. Tian Feiyang \& Zhang Weijia (2014) introduced a new theory of globalization of social linguistics - a new approach to linguistic landscape research. By means of bilingual public signs on Xueyuan Road in Beijing they illuminated the descriptivity and interpretability. Xu Yonggang \& Ren Yan (2015) employed Lijiang as the research site, based on the framework of informational and symbolic functions, by means of qualitative methods, studied the impact of tourism on the Naxi Dongba linguistic landscape. It is one of empirical research on linguistic landscape. Xu Ming \& Lu Song (2015) considered linguistic landscape as an important part of city landscape as well as an important symbol of human geography. On the basis of review on the progress in linguistic research on the linguistic landscape, he looked far ahead into the prospect of geography research on linguistic landscape under the new trend of human geography. Li Lisheng (2015) fully outlined the origins, definitions, functions and some common themes of linguistic landscapes. He provided far-reaching values and insights into the study the language use in linguistic landscapes in China among the domestic scholars. From the above analysis, it is not difficult to conclude that the study on the linguistic landscape is developing fast and drawing more and more attention, though the research is still in the initial stage inchina. Unfortunately, there are only a few scholars who conducted the linguistic landscape research in certain areas of certain cities. Fewer scholars have paid attention to the prosperous language use in the linguistic landscape in minority areas, and the related research or empirical research is less.

\section{Methodology}

\subsection{Research Questions}

The paper endeavors to answer the following questions:

(1) What kinds of languages are used in the linguistic landscape of Fuhui Street and Xinhua Street and what kind of distribution does the language use reveal?

(2) What attitudes do local government officials, shop owners, tourists from home and abroad hold towards the use of Chinese, Dongba scripts, and English in the linguistic landscape of the two streets?

(3) Is it necessary to use English? What kind of roles does English, as a world language, play in the linguistic landscape?

\subsection{Research Instruments}

In the first place, qualitative approach was employed. A camera was used to take photographs. The criteria for the classification of analysis units in the study are following Cenoz \& Gorter's (2006) classification system. The first important decision is to establish the unit of analysis. Cenoz \& Gorter (2006) stated that, "each establishment but not each sign was the unit of analysis, that is, it was considered 'one single sign' for the analysis" (p. 71). Based on this, 329 units of analysis and 213 units of analysis were collected in Fuhui Street and Xinhua Street respectively. Units of analysis in the two streets are different because it is hard and even impossible to control the number with regard to the different language use choice. It is also for the purpose of objectivity. Quantitative approach was also used to facilitate qualitative approach, and the basic data collection methods were employed, namely, unstructured interviews. The interviews were conducted with local government officials, shop owners, tourists from home and abroad. Participants $(n=33)$ were local government officials in Lijiang Old Town district, shop owners or their employees both in Fuhui Street and Xinhua Street, and the tourists both from home and abroad. Except for local government officials, other respondents were randomly selected. Interviews with government officials were conducted in their offices, and the reason why they were chosen was that their daily work was closely related to the linguistic landscape of Lijiang Old Town District. Other interviews were carried out in public streets. All these interviews were conducted in November, 2013. Every interview lasted about 5-10 minutes. All interviews were carried out by the author of the present research. Accordingly, four kinds of face-to-face questionnaires were designed to cater to four different groups respondents. In particular, one questionnaire available to tourists from abroad was in English, and the interviewer asked them these questions in English. Generally speaking, the four kinds of questionnaires all included two parts, the background of the participants and four to seven open questions. The names were code names, i.e. GO for government officials, SO for shop owners or employees, DT for domestic tourists, and IT for international tourists. A total of 33 successful interviews were accomplished. There was some oversampling of males as they accounted for around $57.58 \%$, and females were about $42.42 \%$. Most of the interviews were recorded by means of a recording pen with respondents' approval, except for two respondents who did not accept the recording. 


\subsection{Research Setting}

The paper focuses on two streets in Lijiang Old Town district. Lijiang has the best preserved ancient town in China - the Old Town that has been listed in the World Cultural Heritages by UNESCO (United Nations Educational, Scientific and Cultural Organization) in 1997. Naxi is one of the 55 ethnic groups that officially recognized by the People's Republic of China. The majority of Naxi people live in Lijiang. Naxi people have their own specific written language-Dongba scripts. Under the context of rapid development, communication and government policy encouragement, more and more Naxi people begin to contact with other people, especially with Han people. More importantly, Lijiang's well-known reputation as a World Heritage site positively promotes closer connection with the international world. In consideration of all these facts, the linguistic landscape of Lijiang Old Town district is to be full of diverse features.

Fuhui Street is the street where Lijiang Old Town District People's Government and other relevant governmental agencies located. There are also some banks, Bank of China, China Postal Bank, China Construction Bank, Industrial and Commercial Bank of China, Yunnan Rural Credit Cooperatives. Except for these institutions, most of the research subjects are private shops, restaurants or clothes shops etc. The research scope begins with the intersection of Fuhui Street and Minzhu Street, which is the starting place of Fuhui Street, and it stops at the crossing between Fuhui Street and Xi' an Street.

Xinhua Street is situated in one of the busiest places in Lijiang Old Town. Xinhua Street is near the Square Street, which is the center of Lijiang Old Town. Four main streets radiate from the Square Street, namely, Wuyi Street, Qiyi Street, Xinhua Street, and Huangshan Section, and they farther extend four different directions. Though Fuhui street is longer than Xinhua Street, the signs analysis units are a little more than Xinhua Street's, because there are some missing linguistic landscapes in Fuhui Street.

\section{Findings and Discussions}

\subsection{The Number of Languages, Distribution and Characteristics of Language Signs}

As can be seen in Table 1, in Fuhui Street, among the total the units of analysis (329), more than one fifth $(22.19 \%)$ of the signs was monolingual; and approximately one fourth $(24.01 \%)$ of the signs were bilingual. In contrast, more than half of the signs (53.80\%) were multilingual (three languages). In Xinhua Street, with the total the units of analysis (213), the monolingual signs percentage was only about $7.04 \%$, much less than that in Fuhui Street. The bilingual signs were also less than that in Fuhui Street, since they just accounted for almost one fifth $(20.66 \%)$. It can be easily calculated that multilingual signs percentage in Xinhua Street was more than that in Fuhui Street, roughly $72.30 \%$. It is worth mentioning that there were some signs that contain four languages in the linguistic landscape of Xinhua Street, which can't be found in Fuhui Street. Considering the analysis of the results, it can be concluded that the numbers of languages on signs in Fuhui Street are quite different from in Xinhua Street in overall impression.

Table 1. Number of languages on signs

\begin{tabular}{lll}
\hline Number of languages & Fuhui Street & Xinhua Street \\
\hline 1 & 73 & 15 \\
2 & 79 & 44 \\
3 & 177 & 149 \\
4 & 0 & 5 \\
sum & 329 & 213 \\
\hline
\end{tabular}

As regards the language distribution, and the results were given in Table 2. In view of one language, Chinese characters were definitely the main linguistic landscapes in both streets. Moreover, there emerged only two units of English. Even in Xinhua Street, the law of Protection Regulations for the Naxi Minority's Dongba Culture in Yunnan and Tentative measures for Tourism Management in Lijiang City regulated that Dongba scripts should be on public signs. However, there were still some exceptions. These exceptions could also be found in bilingual signs, which were lack of at least one language, as legal provision of at least three languages on the public signs, Dongba scripts, Chinese characters and at least one foreign language within the domain of Lijiang Old Town. Though there was no definite requirement for what kind of languages people should employ on shop fronts in Fuhui Street, there were still nearly half of public signs (48.02\%) that used three languages, Dongba scripts, Chinese characters and English in the linguistic landscape. While under the law regulations, Xinhua Street had obvious higher percentage, and the proportion was about 58.22\%. One example was shown in Figure 1. 
It is interesting to note some public signs in the language distribution. In Xinhua Street, there were four units of analysis of Chinese characters, English, Japanese and French, which were all public signs designed by the local government. One of the instances was presented in Figure 2. These public signs in the linguistic landscape of Xinhua Street were very eye appealing, because four languages were rare among multilingual signs, and there were no Dongba scripts. One more phenomenon was noteworthy, language contact in Xinhua Street, Chinese characters plus English, Pinyin and Dongba scripts.

Table 2. Language distribution on public signs

\begin{tabular}{lcc}
\hline Language distribution & Fuhui Street & Xinhua Street \\
\hline Chinese characters only & 71 & 15 \\
English only & 2 & 0 \\
Chinese characters \& English(or reverse order) & 57 & 33 \\
Chinese characters \& Dongba scripts(or reverse order) & 12 & 7 \\
Chinese characters \& Pinyin(or reverse order) & 8 & 3 \\
English \& Dongba scripts & 2 & 0 \\
Korean \& Chinese characters & 0 & 1 \\
Dongba scripts, Chinese characters \& English (or in random order) & 158 & 124 \\
Dongba script, Chinese characters \&Pinyin (or in random order) & 17 & 23 \\
Chinese characters+English, Pinyin \& Dongba scripts & 0 & 1 \\
Dongba script, Chinese characters \& Korean & 1 & 0 \\
Arabic, Chinese characters \& English & 1 & 0 \\
Chinese characters, Japanese \& Korean & 0 & 1 \\
Chinese characters, English, Japanese \& French & 0 & 4 \\
Japanese, English, Chinese characters, Japanese+ Korean & 0 & 1 \\
\hline
\end{tabular}

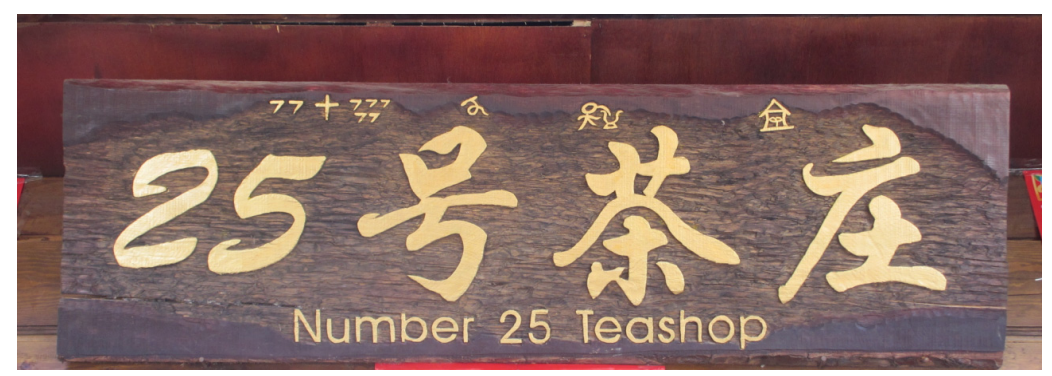

Figure 1. An example of Dongba scripts, Chinese characters and English in Xinhua Street

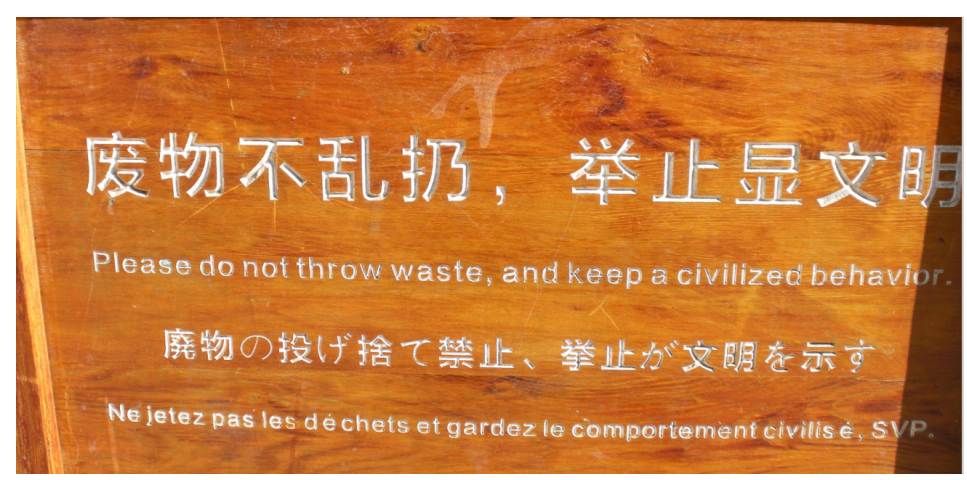

Figure 2. An example of Chinese characters, English, Japanese and French in Xinhua Street

Some factors were considered with regard characteristics of bilingual and multilingual language signs. The first feature of the signs analyzed was the order of languages in the bilingual and multilingual signs. One rule in this study is that the first order language does not mean the most prominent language. In fact, not all the first order languages were the most prominent languages. The results were presented in Table3. 
Table 3. The first language on bilingual and multilingual signs

\begin{tabular}{lll}
\hline The first languages & Fuhui Street & Xinhua Street \\
\hline Chinese characters & 61 & 54 \\
Dongba scripts & 144 & 134 \\
Pinyin & 5 & 1 \\
English & 45 & 7 \\
Arabic & 1 & 0 \\
Korean & 0 & 1 \\
Japanese & 0 & 1 \\
\hline
\end{tabular}

According to the table, it can be easily figured out that, Dongba scripts, as the first minority language in the linguistic landscape of Fuhui Street and Xinhua Street, accounted for roughly 56.25\% and 67.68\% respectively. Both of the numbers were over half of the total signs. In general, the percentage of Xinhua Street was higher than that of Fuhui Street. For English, as an international language, it was about $17.57 \%$ and $3.37 \%$ respectively in Fuhui Street and Xinhua Street. The percentage of the former one was much more than that of the latter one. In sum, it showed that the regulations of the law did play a significant role in Lijiang Old Town, though there should always be exceptions to the rule.

\subsection{The Results of Interviews}

4.2.1 Attitudes Towards the Use of Chinese, Dongba scripts, and English

For this research question, the following Table 5 manifested the interviewees' attitudes towards Chinese, Dongba scripts, and English in a general way.

Table 5. Attitudes towards Chinese, Dongba scripts, and English

\begin{tabular}{|c|c|c|c|}
\hline Interviewees (code names) & Attitude to Chinese & Attitude to Dongba scripts & Attitude to English \\
\hline GO1 & 1 & 1 & 1 \\
\hline GO2 & 1 & 1 & 1 \\
\hline GO3 & 1 & 1 & 1 \\
\hline GO4 & 1 & 1 & 1 \\
\hline GO5 & 1 & 1 & 1 \\
\hline GO6 & 1 & 1 & 1 \\
\hline GO7 & 1 & 3 & 1 \\
\hline $\mathrm{SO} 1$ & 1 & 1 & 1 \\
\hline $\mathrm{SO} 2$ & 1 & 1 & 1 \\
\hline $\mathrm{SO} 3$ & 1 & 1 & 1 \\
\hline $\mathrm{SO} 4$ & 1 & 1 & 1 \\
\hline SO5 & 1 & 3 & 3 \\
\hline SO6 & 1 & 1 & 1 \\
\hline SO7 & 1 & 3 & 1 \\
\hline SO8 & 1 & 2 & 1 \\
\hline SO9 & 1 & 1 & 2 \\
\hline SO10 & 1 & 1 & 1 \\
\hline DT1 & 1 & 1 & 3 \\
\hline DT2 & 1 & 1 & 1 \\
\hline DT3 & 1 & 1 & 3 \\
\hline DT4 & 1 & 1 & 1 \\
\hline DT5 & 1 & 1 & 1 \\
\hline DT6 & 1 & 1 & 1 \\
\hline DT7 & 1 & 1 & 1 \\
\hline DT8 & 1 & 1 & 1 \\
\hline IT1 & 1 & 2 & 1 \\
\hline IT2 & 1 & 2 & 1 \\
\hline IT3 & 1 & 1 & 1 \\
\hline IT4 & 1 & 1 & 2 \\
\hline IT5 & 1 & 1 & 1 \\
\hline IT6 & 1 & 1 & 1 \\
\hline IT7 & 1 & 2 & 1 \\
\hline IT8 & 1 & 2 & 1 \\
\hline
\end{tabular}

Note. 1 equals positive, 2 equals neutral, 3 equals negative. 
As can been from the Table, in the linguistic landscape of Fuhui Street and Xinhua Street, among all the participants, Chinese was supported by all of them; English was favored by $84.85 \%$ of them, and $6.06 \%$ of them remained neutral; Most people (75.76\%) were in favor of Dongba scripts and $15.16 \%$ of them maintained neutrality.

The interviewees' overall impression towards Dongba scripts was bidirectional. Some people said they looked beautiful. Some said they represented cultural symbols and their cultural inheritance. There were some young tourists from home believed that they were kind of fashionable, and interesting.

\section{Excerpt 4.1}

IT6: I think it's (Dongba script) very interesting, and makes feel like it been a very unique place, but I think I' $m$ also not sure how authentic it is, because I don't believe any of the people here can read it, even the Naxi, I don't think, can read it. I think it's interesting but not particularly useful. What makes it feels like a different place.

GO7: In order to give information, you have to use standard words to make people understand. Dongba scripts can't do it. I do not approve of Dongba scripts, because, indeed, even the Naxi people can not read them, what's the use if you put them up?

All the participants reached unanimous agreement on the use of Chinese. They usually used short sentences to express their certainty of Chinese use.

Excerpt 4.2

SO8: Definitely, Chinese must be used. If we only use Dongba scripts and English, there would be more people can not understand them.

DT8: Of course, Chinese should be the first and best choice. China has 56 nationalities, and in order to better communicate with each other, standard language must be adopted. Then, standard Chinese is good.

On the basis of the consistency, tourists from abroad had another voice, Pinyin, which can be easily neglected.

Excerpt 4.3

IT2: Pinyin, it's very important for foreigners. Pinyin is also very necessary. Pinyin, we can read it, because we have a book, so we can read pinyin.

IT5: What I need is pinyin, because I rely on Pinyin a lot and in other parts of China, there are Pinyin everywhere. There is no Pinyin here, not so much. I will be happy to see more Pinyin.

In a general way, the majority of tourists from abroad were positive on the use of Chinese, Dongba scripts and English, and there were some people remained neutral on them. Pinyin was called for according to the interviews, which was unexpected, because pinyin could be recognized by most of the tourists from abroad.

\subsubsection{The Roles of English}

Kachru (1988), the American linguist, came up with the spread of English around as three concentric circles, which showed the way the language has been acquired and is presently used. According to his three concentric circles, China belongs to expanding circle. In fact, it means that our nation recognize the significance of English as an international language. English is taught and learned as a foreign language. One fact is that English constitutes part of the linguistic landscape almost everywhere. The spread of English, as the language for wider communication, had been recorded (Huebner, 2006).

The interviewees' points were presented according to the four groups. Without any doubt, all the government officials believed that, of course, it was necessary to use English in Lijiang Old Town, which was referred to as an International Tourism Town by most of them. When it comes to the roles of English, they had different voices and understandings. In brief, English played a vital role. It especially focused on the following aspects: help, guidance, exhibition, education, tourism, publicity, service, tourists' demand, communication, introduction, foreign tourists' convenience, integration with international standards, keeping pace with the time and promoting the government public service. Most of them mentioned for the foreign tourists' convenience, which was in agreement with Smalley's (1994) claim that English was for the benefit of foreigners. One point needed to add that a couple of officials mentioned the inappropriateness of English. The followings were some excerpts in detail.

Excerpt 4.4

GO3: Since Lijiang is the world's Lijiang, it surely should be open to the world. Deng Xiaoping once said that we should be open up to the world, is it right? Then, if you ask me, as there are more and more tourists, if we 
only use Chinese characters or Dongba scripts, many tourists from abroad might not understand the meanings. Therefore, English is extremely necessary and common. Moreover, English is also a product of an open tourism city. All in all, I think it is very common to see that English appeared on the shop doors or fronts. Its main functions are to advertise and communicate.

GO7: In my point of view, the more English, and other foreign languages, for example, Korean and Japanese, the better. The more foreign languages appear on the shops, billboard, public signs, the more open the city is. At least, when some foreign friends come to visit the town, they do not bother to ask directions. Therefore, they can avoid some troubles. I support the use of English. Its roles are obvious, which is to help and guide foreigners.

Participants of shop owners or employees held different opinions on the necessity of English. Most of them $(90 \%)$ believed that English was good or not bad, while only one person (10\%) did not agree. The latter regarded English as insignificant, because he did not understand English at all or he just forced by the law regulations. The former deemed that English played a large part in communication, devices, serving as a window, the symbol of internationalization and modernity, respect, attracting foreign customers, direction, the language representing the shop products, and integration with international standards. The information for explanation in detail was as follows.

\section{Excerpt 4.5}

SO5: In fact, English in our shop fronts are only the task that the Management Bureau of Lijiang Old Town assigns. We have no choice. If we do not follow the requirement, they would not approve our billboard.

SO10: Because there are so many foreign tourists, English is normal. It also illustrates the integration level of culture internationalization. The local people may read Dongba scripts or Chinese characters, and the foreigners are able to read English.

The majority of tourists (75.00\%) from home were for the use of English, and only one person was against it, because he held that since most tourists were Chinese, English was not necessary. In their view, English was mainly used to show publicity, instruction, introduction, convenience, lead, openness. Some meaningful points were extracted here.

Excerpt 4.6

DT4: Actually, English is a symbol of international status of Lijiang. Essentially, there are many tourists from abroad. English, as an international lingua franca, can be very convenient for them.

DT7: Of course, English, as one of the most commonly used language, can be understood by tourists from abroad. Here, in this Old Town, it has great impact on foreign tourists. But in some places, English writings are not so standard, and they are hard to recognize and understand. So, the writings still need to be improved.

Though the answers of foreign tourists were showing astonishingly consistency of the absolute necessity of English, there were still some other explanations and understanding. To them, in the first place, English was of great help, great significance, of preference, and easy to understand. However, it was still unavoidable to encounter some problems.

\section{Excerpt 4.7}

IT4: I like English, because I can understand it. However, I prefer without it, because I feel more in China rather than Australia. Do you understand? Yeah, it's good, because I can understand it, but I like without it. I feel like I'm in China. But it is in English, I'm not feeling in this country. It is necessary for English speaking tourists. But there're kind of a few errors, it is very funny.

IT5: I don't look at the shop fronts, so I don't see English, I see the menus, I see the down eyes level but I don't see any shops fronts.

IT6: I think it makes me feel like, it shows it is a very commercial and touristy place, many stores, expect many foreign people to come, so it plans to accommodate them with English.

IT7: English is very nice to me, because it's the only one that I can read, I can understand.

IT8: It's useful but it's funny, because most of them do not translate well. The translation sometimes looks funny. Sometimes it's confusing.

In line accordance with the above excerpts, it can be deduced that English was indispensable for the foreign tourists. However, it actually encountered some problems, such as the writing errors, the translation errors. However, they were not our research concerns. Our focus was endeavoring to probe into the real language phenomena, and describe them. 
From all these standpoints, the sine qua non of English was fully affirmed by most of the participants. In an obvious way, English had symbolic and informational function. To a great extent, the appearance of English, as a world language, implied that the globalization trend of the linguistic landscape in Lijiang Old Town District. The conclusion was consistent with Li's (2005) viewpoint, who pointed out that "during the communication of current international languages, English, definitely, has become the world's most popular and powerful language" (p. 104).

\section{Conclusion}

It is high time to point out some similarities and differences between Fuhui Street and Xinhua Street. From the perspective of general impression, the linguistic landscape of Xinhua Street appeared to be more diverse, with more languages and varieties in the public domain. It could be attributed to some relevant laws, especially the regulation, Tentative Measures for Tourism Management in Lijiang City, though there still had quite a few exceptions. This could also explain that monolingual signs of Xinhua Street were less than those of Fuhui Street. Moreover, the multilingual signs of Xinhua Street were much more than those of Xinhua Street. This reveals that the regulations towards the Old Town were highly effective to a large degree.

The numbers of languages on signs in Fuhui Street are quite different from that in Xinhua Street. More than one fifth $(22.19 \%)$ of the signs in Fuhui Street was monolingual; and approximately one fourth $(24.01 \%)$ of the signs were bilingual and $53.80 \%$ of the signs multilingual. In contrast, in Xinhua Street, the monolingual signs percentage was only about $7.04 \%$, the bilingual signs accounted for almost one fifth (20.66\%) and multilingual signs roughly $72.30 \%$.

On the language distribution on signs in the linguistic landscape of the two streets, as mentioned earlier, about the proportion of the three languages, Dongba scripts, Chinese characters and at least one foreign language, Xinhua Street had a clear advantage, though the percentage of Fuhui Street was not so low. In Fuhui Street, the distribution of Chinese characters was much more than that of Xinhua Street. One phenomenon is worthy to be mentioned, the total proportion of English in the linguistic landscape of Fuhui Street was much more than that of Xinhua Street. The main reason is that some shop owners used Pinyin to replace English. Pinyin was just what some tourists from abroad call for. Looking at the linguistic landscape of the two sites, it is a fact that Chinese is the dominant and most salient language, and English played an important role due to the increasing globalization.

The interview results were investigated, which means necessity and attitudes towards the use of Chinese, Dongba scripts, and the roles of English. The use of Chinese was supported unanimously, while the use of Dongba scripts and English was backed by most interviewees. The results of roles of English supported the claim that English's power and status of international, global and world language (Li, 2005; Crystal, 2003), which has influenced the research sites that showed obvious globalization trend. All the respondents were positive towards the use of Chinese in the linguistic landscape of the two streets. Then, almost 17 in 20 were positive on the use of English. Around 3 in 4 were positive on the use of Dongba scripts.

One of the research findings was that the necessity of English was fully affirmed by the absolute majority. Moreover, English was mainly used to help, guide, exhibit, educate, be good to tourism as well as advertise, serve and cater to tourist's demand. In addition, it was also employed to communicate, introduce, give foreign tourists' convenience, integrate with international standards, keep pace with the time, promote the government public service, show respect to foreigners, direct, use as a device, attract foreign customers, to represent shop products, symbolize the internationalization and modernity and the like.

In sum, it is obvious that languages are closely intertwined with public signs. Linguistic landscape deals with languages in written forms. The study shows that the linguistic landscape of Fuhui Street and Xinhua Street has informational, symbolic functions (Landry \& Bourhis, 1997; Ben-Rafael et al., 2001). By and large, the use of English in the linguistic landscape is not only considered as prestigious and modern (Cenoz \& Gorter, 2006), but also is employed apparently to serve tourists, especially foreigners. The last aspect that needed to be pointed out is that, the discussion results of English were also demonstrated its important role in directing, promoting, restricting, and mandatory functions (Bei \& Shan, 2002).

\section{Acknowledgement}

This paper is the research results of the Yunnan provincial Philosophy and Social Sciences Planning Program "An Investigation into the Use of Chinese, minority languages, and English in Cities in the linguistic landscape of Ethnic Autonomous Regions", serial number: YB2013073. 


\section{References}

Backhaus, P. (2007). Linguistic landscapes: A comparative study of urban multilingualism in Tokyo. Clevedon: Multilingual Matters.

Bei, Z., \& Shan, A. M. (2002). Linguistic features of English public signs and Chinese English translation. Journal of Beijing International Studies University, 5, 76-79.

Cenoz, J., \& Gorter, D. (2006). Linguistic landscape and minority languages. International Journal of Multilingualism, 3, 67-80. http://dx.doi.org/10.1080/14790710608668386

Cenoz, J., \& Gorter, D. (2008). The linguistic landscape as an additional source of input in second language acquisition. International Review of Applied Linguistics in Language Teaching, 46(3), 267-287. http://dx.doi.org/10.1515/IRAL.2008.012

Crystal, D. (2003). English as a global language. Cambridge: Cambridge University Press. http://dx.doi.org/10.1017/CBO9780511486999

Landry, R., \& Bourhis, R. Y. (1997). Linguistic landscape and ethnolinguistic vitality: An empirical study. Journal of Language and Social Psychology, 16(1), 23-49. http://dx.doi.org/10.1177/0261927X970161002

Ding, H. Q. (2006). Efforts to improve the city public signs and determine the model reference. Chinese Translators Journal, 6, 42-46.

Li, L. S. (2005). The globalization of English and linguistic diversity. Journal of Yunnan Normal University, 1, 104-107.

Li, L. S. (2015). A Review of linguistic landscape research and its implications. Journal of Beijing International Studies University, 1, 1-7.

Li, P. D. (2015). A study on the translation of public signs from the perspective of critical linguistics. Journal of Ning Xia Normal University, 36(2), 136-140

Luo, X. M., \& Li, T. W. (2006). Translating public signs: Some observations. Chinese Translators Journal, 4, 68-71.

Gorter, D. (Ed.). (2006). Linguistic landscape: A new approach to multilingualism. Clevedon: Multilingual Matters.

Shang, G. W., \& Zhao, S. H. (2014a). Perspectives, theories and methods of the study on linguistic landscape. Foreign Language Teaching and Research, 2, 214-223.

Shang, G. W., \& Zhao, S. H. (2014b). Linguistic landscape studies: analytical dimensions and theoretical construction. Journal of Foreign Languages, 6, 81-89.

Shohamy, E., \& Gorter, D. (Eds.). (2009). Linguistic landscape: Expanding the scenery. New York \& London: Routledge (Taylor and Francis Group).

Shohamy, E., Ben-Rafael, E., \& Monica, B. (Eds.). (2010). Linguistic Landscape in the City. Clevedon: Multilingual Matters.

Sun, L. (2009). The Status quo of linguistic landscape translation and the relevant communicative translation strategies. Jounral of Jiangxi Normal University, 6, 153-156.

Tian, F. Y., \& Zhang, W. J. (2014). The sociolinguistics of globalization as a new theory in linguistic landscape studies: The case of bilingual signs of Xueyuan road in Beijing. Applied Linguistics, 2, 38-45.

Xu M., \& Lu, S. (2015). Research progress and prospect of urban linguistic landscape. Human Geography, 1, 21-25.

Xu, Y. G., \& Ren, Y. (2015). Tourism impact on the Naxi Dongba linguistic landscape. Tourism Tribune, 30(1), $102-110$.

Yang, Y. H. (2009). Review on the translation of public signs in China in the new century. Foreign Language Education, 3, 104-108.

Zhao, X. (2006). Review on the study of public signs translation. Foreign Languages and their Teaching, 12, $52-55$. 


\section{Appendix A}

\section{政府工作人员对丽江语言景观中语言使用的态度访谈问题}

姓名: 性别: 日期:

所在单位及部门:

访谈地点

1. 您好！我们发现在丽江古城许多店铺招牌上、公交车上、路牌上出现了东巴文, 据我所了解几 年前还没有这种现象, 您是否注意到这些变化, 大概什么时候注意到的?

是

您认为是什么原因引起这些变化的? 您认 为这样的变化说明了什么?
否 如果您没有注意到, 现在请您谈谈您的看 法, 您认为这样的变化说明了什么?

2. 请问您觉得政府为什么鼓励在公共标识上使用东巴文字?

3. 除了汉语和东巴文外, 请问您对现在丽江古城区许多店铺门面上使用英语是否有必要, 您认为 它主要的作用是什么, 为什么?

\section{Appendix B}

店铺老板或员工对丽江语言景观中语言使用的态度访谈问题

店铺名称: 性 别:

日 期:

1. 请问店铺招牌上的语言是您自己选择的吗? 您为什么选择这些语言? 您认为这些语言对店铺的 生意有用吗?

2. 请问您对现在丽江古城区许多店铺门面上使用东巴文字是怎么看的?

3. （选择性问答——纳西人）店铺招牌上使用自己本民族的文字——东巴文，您感觉自豪吗？您 感觉使用本民族的文字后自己民族的价值和社会地位有没有变化？如果有，是哪些变化呢？

4. 请问您对现在丽江古城区许多店铺招牌上使用汉语是怎么看的?

5. 请问您对现在丽江古城区许多店铺招牌上使用英语有必要吗? 您是怎么看的? 您认为招牌上的 英语主要起到什么作用,

6. 另外, 我们还发现丽江古城有很多店铺招牌上同时使用东巴文、汉语、英语或者其他外语, 您 觉得使用哪几种语言比较好？您觉得使用这些语言的效果怎么样?

\section{Appendix C}

国内游客对丽江语言景观中语言使用的态度访谈问题

性别:

日期:

来自地区 (省市区):

访谈地点:

1. 请问您对现在丽江古城区许多店铺门面上使用东巴文是怎么看的?

2. 请问您对现在丽江古城区许多店铺招牌上使用汉语是怎么看的?

3. 请问您对现在丽江古城区许多店铺招牌上使用英语有必要吗, 您是怎么看的? 您认为英语主要 起到什么作用?

4. 另外, 我们还发现丽江古城有很多店铺招牌上同时使用东巴文、汉语、英语或者其他外语, 您 觉得使用哪几种语言比较好? 您觉得使用这些语言能有助于国内外的游客了解少数民族语言文化特征 吗? 


\section{Appendix D}

\section{Overseas tourists' attitudes towards the use of languages in the linguistic landscape of Lijiang old town}

Gender: Date:

Country:

Interview spot:

1. What do you think of the use of Dongba scripts on the shop front signs in Lijiang old town?

2. What do you think of the use of Chinese characters on the shop front signs in Lijiang old town?

3. What do you think of the use of English on the shop front signs in Lijiang old town?

4. In your perspective, is it necessary to use the three languages (Dongba scripts, Chinese characters, English) on the shop front signs? Do you think these languages can help tourist to better understand the language and culture characteristics of minorities?

Yes

Which languages help you more?

Would you mind giving us some examples?
No

Please give your reasons.

\section{Appendix E}

\section{Individual interview information}

\begin{tabular}{|c|c|c|c|}
\hline Interviewees(Code names) & Gender & Country/City/nationality & Interview location \\
\hline GO1 & M & Lijiang, Naxi & Civil Affairs Bureau of LJD \\
\hline GO2 & M & Lijiang, Han & Municipal Utilities Bureau of LJD \\
\hline GO3 & $\mathrm{F}$ & Lijiang, Naxi & Education Bureau of LJD \\
\hline $\mathrm{GO} 4$ & M & Lijiang, Naxi & $\begin{array}{l}\text { Intangible Cultural Heritage Protection Center of } \\
\text { Culture and Sports Bureau of LJD }\end{array}$ \\
\hline GO5 & M & Lijiang, Naxi & Xueshan Academy \\
\hline GO6 & $\mathrm{F}$ & Lijiang, Han & Administration of World Cultural Heritage of LJD \\
\hline GO7 & $\mathrm{F}$ & Lijiang, Naxi & Tourism Bureau of LJD \\
\hline SO1 & $\mathrm{F}$ & Dali, Bai & Dongba Paper Workshop \\
\hline $\mathrm{SO} 2$ & $\mathrm{~F}$ & Chongqing, Han & Lijiang Impression T-shirt \\
\hline SO3 & M & Lijiang, Naxi & Dongba Paper Workshop \\
\hline $\mathrm{SO} 4$ & M & Lijiang, Naxi & Wooden Art Studio \\
\hline SO5 & M & Dali, Han & Yunnan Coffee \\
\hline SO6 & M & Xiamen, Han & HP Store \\
\hline $\mathrm{SO} 7$ & M & Baoshan, Han & Natural Spirulina Store \\
\hline SO8 & $\mathrm{F}$ & Chengdu, Han & Dongba Workshop \\
\hline SO9 & M & Lijiang, Yi & Post Office EMS Store \\
\hline SO10 & $\mathrm{F}$ & Lijiang, Naxi & Baisuifang Tea \\
\hline DT1 & M & Shanghai, Han & Entrance of Old Town \\
\hline DT2 & M & Jinan, Han & Square Street \\
\hline DT3 & M & Xi'an, Han & Square Street \\
\hline DT4 & M & Hengyang, Han & Square Street \\
\hline DT5 & $\mathrm{F}$ & Zhaotong, Han & Shuangshi Scetion, Xinhua Street \\
\hline DT6 & M & Hefei, Han & Entrance of Old Town \\
\hline DT7 & $\mathrm{F}$ & Yiyang, Han & Entrance of Old Town \\
\hline DT8 & M & Chongqing, Han & Square Street \\
\hline IT1 & M & France & Huangshan Lower Section of Xinhua Street \\
\hline IT2 & $\mathrm{F}$ & France & Huangshan Lower Section of Xinhua Street \\
\hline IT3 & M & Malaysia & Square Street \\
\hline IT4 & $\mathrm{F}$ & Australia & Qiyi Street \\
\hline IT5 & $\mathrm{F}$ & America & Qiyi Street \\
\hline IT6 & M & Canada & Qiyi Street \\
\hline IT7 & $\mathrm{F}$ & Netherlands & Qiyi Street \\
\hline IT8 & $\mathrm{F}$ & Netherlands & Qiyi Street \\
\hline
\end{tabular}




\section{Copyrights}

Copyright for this article is retained by the author(s), with first publication rights granted to the journal.

This is an open-access article distributed under the terms and conditions of the Creative Commons Attribution license (http://creativecommons.org/licenses/by/3.0/). 